\title{
Research Study on 'Entrepreneurship and Innovation - The Need of the Hour' (An Excerpt from Doctoral Research)
}

\author{
Dr. Shagufta Sayyed \\ (Sinhgad Institute of Business Administration and Research/University of Pune/India)
}

\begin{abstract}
Entrepreneur is someone who perceives opportunity, organizes resources needed, takes initiative, and accepts risk of failure. Intrapreneur is an entrepreneur within an already established organization.As innovation is increasingly recognized as a vital component of entrepreneurship, researchers and educators struggle to reform enterprise pedagogy. To help in the effort to analyze the impact of competencies on business success, the researcher uses a personality test and open-ended interviews to explore the presence of the competency innovation between two groups- entrepreneurs and intrapreneurs. The term intrapreneur has been used interchangeably with employee during the analysis stage.

The objectives of the study are to evaluate whether innovation is the key element in the strategy for business success and to compare the presence of this quality among entrepreneurs and intrapreneurs. The findings indicate that both groups have high innovative potential, but entrepreneurs channeled this into practical and incremental efforts by starting up an enterprise whereas the intrapreneurs were more speculative and had picked up safety of employment in a large business house. The findings drawn also indicate that "Innovativeness" is not necessarily reflected in intrapreneurs for business success but are present in successful entrepreneurs.
\end{abstract}

Keywords: Competency, Entrepreneurs, Entrepreneurship, Innovativeness, Intrapreneur.

\section{Introduction}

Practically everything we use today would have been unthinkable in 1899 - cell phones, laptop computers, digital cameras, debit cards and laser eye surgery. Most of the modern conveniences we take for granted today did not exist 100 years ago. The progress sparked by entrepreneurs' ideas does not simply happen. A tremendous amount of work and a great deal of risk go into every new idea that eventually makes its way into the marketplace.

Innovations add the spark of creativity to the resources in hopes of entrepreneurship development and creating something that others will value.

Entrepreneurial development in India occurs in 'far more encompassing and far reaching ways than in developed countries', and could therefore be far more complex, 'for there is so much more that needs to be done'. Commentators today celebrate the ubiquitous Indian attitude of 'Jugaad' (a Hindi word roughly translated as 'creative improvisation... a tool to somehow find a solution based on a refusal to accept defeat, and calling on initiative, quick thinking, cunning and resolve...) to quickly fulfill market demands at the lowest possible prices as an entrepreneurial trait that has been as much a part of everyday Indian living as its rich tradition of philosophy and speculation.

In this situation, India enjoys enormous potential for the creation of wealth through knowledge. Entrepreneurship and Innovation are the key drivers for generating wealth from knowledge, supported principally by the availability of skilled human resources, access to finance and the ability of the State to create an enabling environment.

Given the increasing significance and visible impact of Entrepreneurial development in wealth-creation and employment generation, the researcher considered the subject to be of immense importance in India's growth and development. This study explores the behavioural factors that have advanced Entrepreneurial development in India as also various others that could further encourage and facilitate even greater growth. The behavioural factor 'Innovativeness' is specifically referred to in this study.

This study measures the impact of Innovativeness as a competency on the business success for entrepreneurs as well as employees. In the following section the theoretical framework is discussed followed by Research Methodology and empirical examination of the research questions.

\section{Literature Review}

2.1 Entrepreneur- An entrepreneur is a person who comes up with new idea and or capital to take the idea to the marketplace. Entrepreneurs improve established products and services, or they create new ones. 
2.2 Competency- A competency as an underlying characteristic exhibited by a person that can result in effective and/or superior job.

2.3 Innovation- The researcher introduced innovation in this study, defining it as the ability to acquire and systematize the operating resources needed to start and grow an organization. Entrepreneurs' innovation involves finding capital and human resources and setting up new operations and new systems (Stevenson, 1985) (Bhide, 2000)

\subsection{The Relationship Between Competency,Innovation And Entrepreneur}

These individuals are directly responsible for revolutionary changes in their organization. They are social innovators and change agents, seeing the big picture and thinking strategically.

The researcher introduced innovation in this study, defining it as the ability to acquire and systematize the operating resources needed to start and grow an organization. Entrepreneurs' innovation involves finding capital and human resources and setting up new operations and new systems (Stevenson, 1985) (Bhide, 2000)

Successful entrepreneurs must know how to search for and acquire financial and human resources, even while confronting new markets, resource shortages, and extreme uncertainty (Smith, 2000)

It may appear that innovation is similar to organizational skill, as studied in (Baum, Locke, \& Smith, 2001); however, organizational skill is defined there as a general management skill involving oral presentation, use of power, diagnosis, and decision making. It involves managing established resources in established settings. In comparison, we conceive of innovation as relating to resources that are new to the organization.

The entrepreneur's skill with integration, or systematization, of resources may make or break a start-up. Indeed, entrepreneurship has been described as the acquisition, combination, and redeployment of resources to provide new products and services through new organizations to new markets. Furthermore, (Smith, 2000) suggested that entrepreneurs' successful efforts to arrange and organize resources are predictors of new venture success. Indeed, founders often experience limited growth because they lack innovation or fail to employ individuals who are skilled with resources (Timmons, 2000). Thus, the researcher hypothesizes direct effects upon venture growth.

An entrepreneur who recognizes that he or she has insufficient capability to create a growing venture may reflect the deficiency by setting lower goals. Those who believe they have high levels of skill should be confident enough to set high goals. The researcher proposes that:

The greater the entrepreneur-CEO's innovation, the greater the goals and higher the subsequent venture growth will be.

Central in social-cognitive theory is the proposition that self-efficacy is affected by enactive mastery, that is, skill through practice (Bandura, 1997). At the root of this proposition is that people are more confident about task performance when they believe they have sufficient innovative skill due to experience or deliberate practice. We expect that entrepreneur-CEOs who have innovative skills will recognize their competency and hold beliefs about their ability to create and guide their organization to growth.

\subsection{Research Method -Survey Method}

\section{Methodology}

3.2 Sampling Technique - Simple random sampling technique is used for the sample of respondents where the strata are the subgroups representing the different business sectors and or sizes. Entrepreneurs are selected from Pune region.

\subsection{Sample - 100 respondents}

The sample population was almost entirely composed of professionals in corporate and entrepreneurs.

A total of 122 responses to the survey were achieved, of which only 100 respondents had completed the entire survey. The 22 respondents who did not complete the survey were dropped from the data set in order to maintain accuracy in the data analysis and tests.

This research takes the opinion that considers owner manager of a business as an entrepreneur thus not limiting the definition of an entrepreneur to new ventures.

\subsection{Instrument - Questionnaire}

In the survey the respondents were asked 30 questions that pertained to their level of entrepreneurial competencies. Each question belonged to one of the competencies. The questions were in the form of statements. The personal traits context questions were given on ordinal scale thus used to classify data into distinct categories which can then be ranked. The questionnaire administered had self-context questions as well as personal traits context questions. 


\subsection{Scales}

A five point Likert scale was used where 1 is "Strongly Disagree", 2 is "Disagree", 4 is "Agree" and 5 is "Strongly Agree" with 3 being "Neutral". The respondent was required to select one of the options for each question in this closed ended questionnaire. The degree of agreement or disagreement to each of the 30 statements would then be given by the answers. The answers were then aggregated to the competency it belonged to in order to determine an overall score for each of the six competencies.

\section{Hypotheses}

$\mathbf{H}_{1}$ : Innovativeness is a significant predictor of business success.

$\mathbf{H}_{2}$ : Innovativeness is a predictor of business success of entrepreneurs.

$\mathbf{H}_{3}$ : Innovativeness is a predictor of business success of intrapreneurs.

\section{Testing Of Hypotheses}

4.1 Hypothesis 1

Multiple Regression Analysis

\subsubsection{Purpose}

To study whether the quality "Innovativeness" positively affects business success.

\subsubsection{Statistical Test}

Multiple Regression Analysis using backward method

\subsubsection{Null Hypothesis}

$\mathbf{H}_{\mathbf{0}}$ : "Innovativeness" is not a predictor of business success.

\subsubsection{Alternate Hypothesis}

$\mathbf{H}_{1}$ : "Innovativeness" is a significant predictor of business success.

Level of significance: $\alpha=0.05$

Table 1: Multiple Regression Analysis model summary table

\begin{tabular}{|l|l|l|l|l|}
\hline Model & $\mathrm{R}$ & $\mathrm{R}$ Square & Adjusted R Square & $\begin{array}{l}\text { Std. Error of the } \\
\text { Estimate }\end{array}$ \\
\hline 1 & $.643^{\mathrm{a}}$ & .413 & .375 & .46712 \\
\hline 2 & $.643^{\mathrm{b}}$ & .413 & .382 & .46466 \\
\hline 3 & $.641^{\mathrm{c}}$ & .411 & .387 & .46296 \\
\hline 4 & $.631^{\mathrm{d}}$ & .379 & .46582 \\
\hline a. & .398 & \\
\hline b. Pependent Variable: Success status of business \\
\hline
\end{tabular}

Model summary shows $3 R$ s viz. $R, R^{2}$ and adjusted $R^{2}$. $R$ is the multiple correlation between the dependent and independent variables, $R^{2}$ is the coefficient multiple determination. Adjusted $R^{2}$ is the adjustment $\mathrm{R}^{2}$ considering number of sample size and independent variables.

\section{Model 1}

\section{Model 4}

$$
\begin{aligned}
& \mathrm{R}=0.0643 \\
& \mathrm{R}^{2}=0.413 \\
& \text { Adjusted } \mathrm{R}^{2}=0.375
\end{aligned}
$$

Insignificant variables removed i.e. leadership, high powered and internal locus of control.

$$
\begin{aligned}
& \mathrm{R}=0.631 \\
& \mathrm{R}^{2}=0.398 \\
& \text { Adjusted } \mathrm{R}^{2}=0.379
\end{aligned}
$$

It is interesting to note that there is no much change in the $3 \mathrm{R}$ values after the removal of insignificant variables in Model 4.

$\mathrm{R}^{2}$ value of 0.398 shows that almost $40 \%$ of the variance in the dependent variable (business success) is explained by the 3 independent variable visionary, innovativeness, risk taker.

In this paper we will be discussing about only innovativeness as independent variable 
Research Study on 'Entrepreneurship and Innovation - The Need of the Hour' (An Excerpt ...

Table 2: ANOVA $^{\mathrm{a}}$ test results

\begin{tabular}{|c|c|c|c|c|c|c|}
\hline \multicolumn{2}{|c|}{ Model } & Sum of Squares & df & Mean Square & $\mathrm{F}$ & Sig. \\
\hline \multirow{3}{*}{1} & Regression & 14.297 & 6 & 2.383 & 10.921 & $.000^{\mathrm{b}}$ \\
\hline & Residual & 20.293 & 93 & .218 & & \\
\hline & Total & 34.590 & 99 & & & \\
\hline \multirow{3}{*}{2} & Regression & 14.295 & 5 & 2.859 & 13.241 & $.000^{\mathrm{c}}$ \\
\hline & Residual & 20.295 & 94 & .216 & & \\
\hline & Total & 34.590 & 99 & & & \\
\hline \multirow{3}{*}{3} & Regression & 14.228 & 4 & 3.557 & 16.596 & $.000^{\mathrm{d}}$ \\
\hline & Residual & 20.362 & 95 & .214 & & \\
\hline & Total & 34.590 & 99 & & & \\
\hline \multirow{3}{*}{4} & Regression & 13.760 & 3 & 4.587 & 21.138 & $.000^{\mathrm{e}}$ \\
\hline & Residual & 20.830 & 96 & .217 & & \\
\hline & Total & 34.590 & 99 & & & \\
\hline
\end{tabular}

ANOVA table is significant for all the four models

$\mathrm{F}(3,96)=21.138$, $\mathrm{p}$-value $<0.05$.

Since the overall model is significant we refer to coefficients table to understand $\beta$ coefficient of the independent variable.

Table 3: Regression Coefficients test results

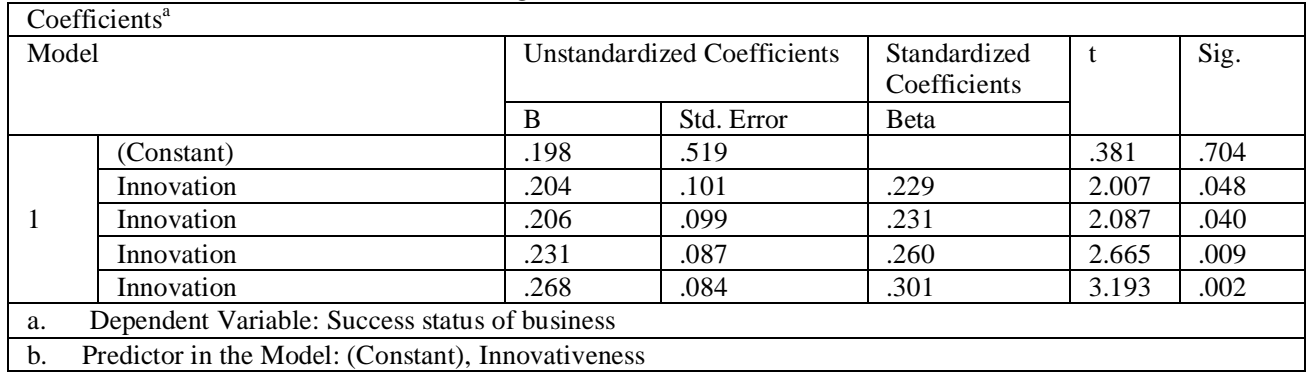

Table 4: Residuals Statistics ${ }^{\mathrm{a}}$

\begin{tabular}{|l|l|l|l|l|l|}
\hline & Minimum & Maximum & Mean & Std. Deviation & $\mathrm{N}$ \\
\hline Predicted Value & 2.6046 & 4.4679 & 3.7100 & .37281 & 100 \\
\hline Residual & -1.01387 & 1.30412 & .00000 & .45870 & 100 \\
\hline Std. Predicted Value & -2.965 & 2.033 & .000 & 1.000 & 100 \\
\hline Std. Residual & -2.177 & 2.800 & .000 & .985 & 100 \\
\hline a. Dependent Variable: Success status of business \\
\hline
\end{tabular}

For innovativeness $b=0.268, t=3.193$, $p$-value $<0.05$.

Thus the multiple regression equation can be presented as follows:

Business success $=0.268$ ("Innovativeness")

\subsubsection{Inference}

We therefore conclude that:

When "Innovativeness" is increased by 1 unit business succeeds by 0.268 units while the remaining two variables remain constant.

Therefore "Innovativeness" is the important quality for business success.

Multicollinearity is not a problem since Tolerance is above 0.1 for all the variables. 


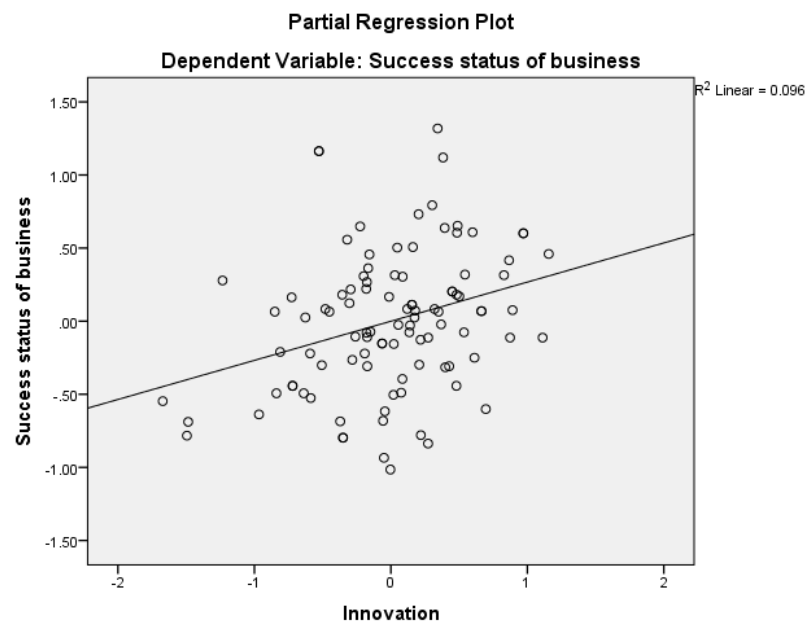

Fig. 1: Partial Regression Plot for dependent variable Success status of business for the construct innovation

There is positive relationship between success status of business and innovation since the regression line shows an uphill.

The data suggests that the competency of innovativeness is the important quality for business success.

\subsubsection{Decision:}

Reject the Null Hypothesis: "Innovativeness" is not predictor of business success.

\subsection{Hypothesis 2}

\section{Multiple Regression Analysis}

(split of entrepreneurs and employees)

The following descriptive statistics have been separated into the two groups created to test the hypothesis:

- Respondents who are entrepreneurs (self employed)

- Respondents who are employees/intrapreneurs (employed in leadership positions)

\subsubsection{Purpose}

To study the presence of competency like "Innovativeness" and the business success of entrepreneurs.

\subsubsection{Statistical Test}

Multiple Regression Analysis using backward method

\subsubsection{Null Hypothesis}

$\mathbf{H}_{0}$ : "Innovativeness" is not the predictors for business success of entrepreneurs.

\subsubsection{Alternative Hypothesis}

$\mathbf{H}_{1}$ : "Innovativeness" is a predictor of business success of entrepreneurs.

\subsection{Hypothesis 3}

\subsubsection{Purpose}

To study the presence of competency like "Innovativeness" and the business success of employees.

\subsubsection{Statistical Test}

Multiple Regression Analysis using backward method

\subsubsection{Null Hypothesis}

$\mathbf{H}_{0}$ : "Innovativeness" is not the predictors for business success of employees.

\subsubsection{Alternative Hypothesis}

$\mathbf{H}_{1}$ : "Innovativeness" is a predictor of business success of employees.

Level of significance $\alpha=0.05$. 
Research Study on 'Entrepreneurship and Innovation - The Need of the Hour' (An Excerpt ...

Table 5: Multiple Regression Analysis model summary table

\begin{tabular}{|l|l|l|l|l|}
\hline Designation & Model & Variables Entered & $\begin{array}{l}\text { Variables } \\
\text { Removed }\end{array}$ & Method \\
\hline Employee & 1 & $\begin{array}{l}\text { Visionary, Risk taking, Leadership, Internal Locus } \\
\text { of Control, High powered, Innovation }\end{array}$ & $\cdot$ & Enter \\
\hline Entrepreneur & 1 & $\begin{array}{l}\text { Visionary, Risk taking, High powered, Internal } \\
\text { Locus of Control, Leadership, Innovation }\end{array}$ &. & Enter \\
\hline a. Dependent Variable: Success status of business & \\
\hline b. All requested variables entered.
\end{tabular}

Model summary shows 3 Rs viz. $\mathrm{R}, \mathrm{R}^{2}$ and adjusted $\mathrm{R}^{2}$.

$\mathrm{R}$ is the multiple correlation between the dependent and independent variables.

$\mathrm{R}^{2}$ is the coefficient multiple determination.

Adjusted $\mathrm{R}^{2}$ is the adjustment $\mathrm{R}^{2}$ considering number of sample size and independent variables.

Table 6: Multiple Regression Analysis Model Summary ${ }^{\mathrm{b}}$ table

\begin{tabular}{|c|c|c|c|c|c|}
\hline Designation & Model & $\mathrm{R}$ & R Square & Adjusted R Square & Std. Error of the Estimate \\
\hline Employee & 1 & $.672^{\mathrm{a}}$ & .452 & .390 & .48320 \\
\hline Entrepreneur & 1 & $.555^{\mathrm{c}}$ & .308 & .182 & 44862 \\
\hline \multicolumn{6}{|c|}{ a. Dependent Variable: Success status of business } \\
\hline \multicolumn{6}{|c|}{$\begin{array}{l}\text { a. b. Predictors: (Constant), Visionary, Risk Taking, Leadership, Internal Locus of Control, High powered, } \\
\text { Innovation }\end{array}$} \\
\hline \multicolumn{6}{|c|}{$\begin{array}{l}\text { b. c. Predictors: (Constant), Visionary, Risk Taking, High powered, Internal Locus of Control, Leadership } \\
\text { Innovation }\end{array}$} \\
\hline
\end{tabular}

Employee

MODEL 1

$\mathrm{R}=0.0672$

$\mathrm{R}^{2}=0.452$

Adjusted $\mathrm{R}^{2}=0.390$

Entrepreneur

MODEL 1

$$
\begin{aligned}
& \mathrm{R}=0.555 \\
& \mathrm{R}^{2}=0.308 \\
& \text { Adjusted } \mathrm{R}^{2}=0.182
\end{aligned}
$$

\begin{tabular}{|c|c|c|c|c|c|c|c|}
\hline \multicolumn{8}{|l|}{ ANOVA $^{\mathrm{a}}$} \\
\hline Designation & \multicolumn{2}{|c|}{ Model } & $\begin{array}{ll}\text { Sum } & \text { of } \\
\text { Squares } & \end{array}$ & $\mathrm{df}$ & $\begin{array}{l}\text { Mean } \\
\text { Square }\end{array}$ & $\mathrm{F}$ & Sig. \\
\hline \multirow[t]{3}{*}{ Employee } & \multirow[t]{3}{*}{1} & Regression & 10.209 & 6 & 1.701 & 7.287 & $.000^{\mathrm{b}}$ \\
\hline & & Residual & 12.375 & 53 & .233 & & \\
\hline & & Total & 22.583 & 59 & & & \\
\hline \multirow[t]{3}{*}{ Entrepreneur } & \multirow[t]{3}{*}{1} & Regression & 2.958 & 6 & .493 & 2.450 & $.045^{\mathrm{c}}$ \\
\hline & & Residual & 6.642 & 33 & .201 & & \\
\hline & & Total & 9.600 & 39 & & & \\
\hline \multicolumn{8}{|c|}{ a. Dependent Variable: Success status of business } \\
\hline \multicolumn{8}{|c|}{$\begin{array}{l}\text { b. b. Predictors: (Constant), Visionary, Risk taking, Leadership, Internal Locus of Control 1, High powered, } \\
\text { Innovation. }\end{array}$} \\
\hline \multicolumn{8}{|c|}{$\begin{array}{l}\text { c. Predictors: (Constant), Visionary, Risk taking, High powered, Internal Locus of Control, Leadership, } \\
\text { Innovation. }\end{array}$} \\
\hline
\end{tabular}

Table 7: ANOVA $^{\mathrm{a}}$ test results

\begin{tabular}{|c|c|c|c|c|c|}
\hline \multirow[t]{2}{*}{ Designation } & \multirow{2}{*}{\multicolumn{2}{|c|}{ Model }} & \multicolumn{2}{|c|}{$\begin{array}{l}\text { Unstandardized } \\
\text { Coefficients }\end{array}$} & \multirow{2}{*}{$\begin{array}{l}\text { Standardized } \\
\text { Coefficients } \\
\text { Beta } \\
\end{array}$} \\
\hline & & & $\mathrm{B}$ & Std. Error & \\
\hline \multirow[t]{7}{*}{ Employee } & \multirow[t]{7}{*}{1} & (Constant) & -.479 & .667 & \\
\hline & & High powered & .307 & .149 & .290 \\
\hline & & Risk taking & .407 & .121 & .357 \\
\hline & & Innovation & .083 & .144 & .090 \\
\hline & & Internal Locus of Control & -.022 & .124 & -.022 \\
\hline & & Leadership & .135 & .160 & .117 \\
\hline & & Visionary & .264 & .136 & .270 \\
\hline \multirow[t]{2}{*}{ Entrepreneur } & \multirow[t]{2}{*}{1} & (Constant) & 1.907 & 1.175 & \\
\hline & & High powered & .074 & .197 & .058 \\
\hline
\end{tabular}

Table 8: Regression Coefficients test resultsCoefficients ${ }^{\mathrm{a}}$ 
Research Study on 'Entrepreneurship and Innovation - The Need of the Hour' (An Excerpt ...

\begin{tabular}{|l|l|l|l|l|}
\hline Designation & Model & \multicolumn{2}{l|}{$\begin{array}{l}\text { Unstandardized } \\
\text { Coefficients }\end{array}$} & $\begin{array}{l}\text { Standardized } \\
\text { Coefficients }\end{array}$ \\
\cline { 3 - 5 } & & B & Std. Error & Beta \\
\cline { 3 - 5 } & Risk taking & .044 & .132 & .058 \\
\cline { 3 - 5 } & Innovation & .368 & .163 & .490 \\
\cline { 3 - 5 } & Internal Locus of Control & -.108 & .180 & -.113 \\
\cline { 2 - 5 } & Leadership & -.098 & .179 & -.099 \\
\cline { 2 - 5 } & Visionary & .214 & .171 & .216 \\
\hline
\end{tabular}

\begin{tabular}{|c|c|c|c|c|}
\hline \multicolumn{5}{|l|}{ Coefficients $^{\mathrm{a}}$} \\
\hline Designation & \multicolumn{2}{|c|}{ Model } & $\mathrm{t}$ & Sig. \\
\hline \multirow[t]{7}{*}{ Employee } & \multirow{7}{*}{1} & (Constant) & -.719 & .475 \\
\hline & & High powered & 2.063 & .044 \\
\hline & & Risk taking & 3.358 & .001 \\
\hline & & Innovation & .577 & .567 \\
\hline & & Internal Locus of Control & -.178 & .859 \\
\hline & & Leadership & .845 & .402 \\
\hline & & Visionary & 1.942 & .057 \\
\hline \multirow[t]{7}{*}{ Entrepreneur } & \multirow{7}{*}{1} & (Constant) & 1.623 & .114 \\
\hline & & High powered & .374 & .711 \\
\hline & & Risk taking & .337 & .738 \\
\hline & & Innovation & 2.260 & .031 \\
\hline & & Internal Locus of Control & -.600 & .553 \\
\hline & & Leadership & -.544 & .590 \\
\hline & & Visionary & 1.252 & .219 \\
\hline
\end{tabular}

Table 9: Residuals Statistics ${ }^{\mathrm{a}}$

\begin{tabular}{|l|l|l|l|l|l|l|}
\hline \multicolumn{2}{|l|}{ Residuals Statistics $^{\mathrm{a}}$} & Minimum & Maximum & Mean & Std. Deviation & $\mathrm{N}$ \\
\hline Designation & Predicted Value & 2.3099 & 4.4407 & 3.5833 & .41596 & 60 \\
\hline \multirow{4}{*}{ Employee } & Residual & -1.01702 & 1.06530 & .00000 & .45798 & 60 \\
\cline { 2 - 7 } & Std. Predicted Value & -3.061 & 2.061 & .000 & 1.000 & 60 \\
\cline { 2 - 7 } & Std. Residual & -2.105 & 2.205 & .000 & .948 & 60 \\
\hline \multirow{5}{*}{ Entrepreneur } & Predicted Value & 3.3810 & 4.4967 & 3.9000 & .27541 & 40 \\
\cline { 2 - 7 } & Residual & -.86827 & 1.15935 & .00000 & .41267 & 40 \\
\cline { 2 - 7 } & Std. Predicted Value & -1.884 & 2.167 & .000 & 1.000 & 40 \\
\cline { 2 - 8 } & Std. Residual & -1.935 & 2.584 & .000 & .920 & 40 \\
\hline \multirow{2}{*}{ a. Dependent Variable: Success status of business } & & & \\
\end{tabular}

For Entrepreneur

For innovativeness $b=0.368, t=2.260, p$-value $=0.031$

When innovativeness is increased by 1 unit business succeeds by 0.368 unit.

Thus the multiple regression equation can be presented as follows:

Entrepreneur Business success $=1.907+0.368$ (innovativeness)

\subsubsection{Inference}

The data suggests that the competency of innovativeness is the important quality and predictor for business success for entrepreneurs.

\subsection{8decision}

Reject the Null Hypothesis: "Innovativeness" is not the predictor for business success of entrepreneurs.

For Employee

For High powered $\mathrm{b}=0.307, \mathrm{t}=2.063$, $\mathrm{p}$-value $=0.044$

For risk taking $\mathrm{b}=0.407, \mathrm{t}=3.358, \mathrm{p}$-value $=0.001$

But for innovativeness $b=0.083, t=0.577, p$-value $=0.567$

\subsubsection{Inference}

We therefore conclude that 
When High powered is increased by 1 unit business succeeds by 0.307 units while the remaining variables remain constant.

When risk taking is increased by 1 unit business succeeds by 0.407 unit while the remaining variables remain constant.

Therefore High powered, risk taking are the important qualities for business success for employees.

Employee Business success $=-0.479+0.307$ (high powered) +0.407 (Risk taking)

The data suggests that the competency like "Innovativeness" is not the most important quality required or predictors for business success of employees

\subsubsection{0decision}

Accept the Null Hypothesis: "Innovativeness" is not the predictor for business success of employees

\subsubsection{Findings $\&$ Results}

1. The competency "Innovativeness" showed the following results For Levene's test $\mathrm{F}=0.252, \mathrm{t}(84.446)=$ -.615 , p-value $(0.541)$

2. Hence the conclusion is that the competency of being "Innovative" is independent of the position. Both employees and entrepreneurs reflect this quality.

3. Hence it is analyzed that "Innovativeness" is a competency that is predictor of business success for an Entrepreneur but not necessarily for the Intrapreneur/Employee.

Table 10: Summary of Results of Hypotheses Testing

\begin{tabular}{|l|l|l|l|l|}
\hline & Construct & Hypotheses & Result & Decision \\
\hline $\mathrm{H}_{1}$ & $\begin{array}{l}\text { "Innovativeness" } \\
\text { predictor of business } \\
\text { success }\end{array}$ & $\begin{array}{l}\text { "Innovativeness" is not a predictor of } \\
\text { business success. } \\
\text { Entrepreneurs }\end{array}$ & $\begin{array}{l}\mathrm{F}(3,96)=21.138, \\
\mathrm{p} \text {-value }<0.05\end{array}$ & Reject Null \\
\hline $\mathrm{H}_{2}$ & $\begin{array}{l}\text { "Innovativeness" and } \\
\text { "Innovativeness" is not the predictors for } \\
\text { business success of entrepreneurs. }\end{array}$ & $\begin{array}{l}\text { For innovativeness } \\
\mathrm{b}=0.368, \\
\mathrm{t}=2.260, \\
\mathrm{p} \text {-value=0.031 }\end{array}$ & Reject Null \\
\hline $\mathrm{H}_{3}$ & $\begin{array}{l}\text { "Innovativeness" and } \\
\text { Intrapreneurs }\end{array}$ & $\begin{array}{l}\text { "Innovativeness" is not the predictors for } \\
\text { business success of employees. } \\
\mathrm{b}=0.083, \\
\mathrm{t}=0.577, \\
\mathrm{p} \text {-value=0.567 }\end{array}$ & Accept Null \\
\hline
\end{tabular}

\section{Figures and Tables}

\begin{tabular}{|c|c|}
\hline Table & Details \\
\hline Fig. 1: & $\begin{array}{l}\text { Partial Regression Plot for dependent variable Success status of business for } \\
\text { the construct innovation }\end{array}$ \\
\hline TABLE 1: & Multiple Regression Analysis model summary table \\
\hline TABLE 2: & ANOVA $^{\text {a }}$ test results \\
\hline TABLE 3: & Regression Coefficients test results \\
\hline TABLE 4: & Residuals Statistics $^{\mathrm{a}}$ \\
\hline TABLE 5: & Multiple Regression Analysis model summary table \\
\hline TABLE 6: & Multiple Regression Analysis Model Summary ${ }^{\mathrm{b}}$ table \\
\hline TABLE 7: & ANOVA $^{\text {a }}$ test results \\
\hline TABLE 8: & 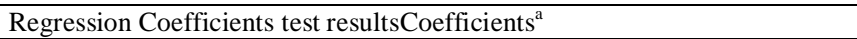 \\
\hline TABLE 9: & Residuals Statistics $^{\mathrm{a}}$ \\
\hline TABLE 10: & Summary of Results of Hypotheses Testing \\
\hline
\end{tabular}

\section{Conclusion and Suggestion}

The entrepreneur is the who implements 'new combinations of means of production' plays a crucial role in disturbing the status quo through Innovation - or 'creative destruction' - and thereby becomes an agent of change. As such, the 'dynamic equilibrium' achieved by a constantly innovating entrepreneur could generate the conditions for:

a. increasing opportunities for employment (comprising various competitive skill sets);

b. additional wealth creation;

c. introduction and dissemination of new methods and technology; and

d. overall economic growth.

Successful Entrepreneurship ecosystem is the function of a number of factors working in tandem. These are classified as 'Entrepreneurial Triggers'. One such trigger is "Innovativeness". 
Innovations can be used to improve things, come up with new products, come up with enhancements, etc. While not practicing innovation can prove costly in terms of letting go of ideas and opportunities, spending more than required time and money on the same can also lead to loss of valuable productive time.

The diffusion of innovation theory helps entrepreneur to understand that a radical innovation gains market acceptance in stages. Innovators need to understand two basic concepts of diffusion; one is Innovation and the other is the Right Timing in Product Creation and Launch.

Blue ocean strategy is suggested to the entrepreneur. It looks at new areas that can allow organisations to come up with unmet business opportunities. Blue oceans are places where there is nobody and the entire market is available. Rather, the market has to be created and then taken up by the enterprises. By this reasoning discovering of a blue ocean for an enterprise is hugely profitable than a strong innovation in a red ocean.

India has a rich tradition of Entrepreneurship, practised in diverse ways. Entrepreneurship is embedded in the Indian mindset. After economic liberalization, there has been increased salience of Entrepreneurial development in India, particularly in the high growth and knowledge intensive sectors.

New entrepreneurs who do not belong to traditional business communities have begun to emerge in large numbers. Entrepreneurship has grown rapidly, visibly so, creating wealth and generating employment, especially in the past twenty years.

The positive contribution of Pune entrepreneurs is reflected in their contribution to job creation. My preliminary estimates suggest that in Pune, the number of jobs created by legitimate businesses - small or large in the Software and Software Related Services Sector - have been modest.

Future data-based research studies addressing Psychological Traits, Environmental and Sociological Influences on entrepreneurial orientations should employ a more representative sample from multiple industries with provisions for inter-industry variations in life cycles.

\section{References}

[1]. Stevenson, H. H. (1985). A new paradigm for entrepreneurial management. In J. J. Kao \& H. H. Stevenson (Eds.), Entrepreneurship: What it is and how to teach it (pp. 30-61). Boston: Harvard Business School.

[2]. Bhide, A. V. (2000). The origin and evolution of new businesses.New York: Oxford University Press.

[3]. Stevenson, H. H. (1985). A new paradigm for entrepreneurial management. In J. J. Kao \& H. H. Stevenson (Eds.), Entrepreneurship: What it is and how to teach it (pp. 30-61). Boston: Harvard Business School.

[4]. Bhide, A. V. (2000). The origin and evolution of new businesses.New York: Oxford University Press.

[5]. Smith, J. K., \& Smith, R. L. (2000).Entrepreneurial finance. New York: Wiley.

[6]. Baum, J. R., Locke, E. A., \& Smith, K. G. (2001).A multidimensional model of venture growth. Academy of Management Journal, 44, 292-303.

[7]. Smith, J. K., \& Smith, R. L. (2000).Entrepreneurial finance. New York: Wiley.

[8]. Timmons, J.A. \&Spinelli, S. (2007). New Venture Creation. Boston: McGraw-Hill.

[9]. Bandura, A. (1997). Self-efficacy: The exercise of control. New York: Freeman. 